\title{
Role of Phospholipid Head Groups in Ethanol Tolerance of Saccharomyces cerevisiae
}

\author{
By PRASHANT MISHRA AND RAJENDRA PRASAD* \\ School of Life Sciences, Jawaharlal Nehru University, New Delhi 110 067, India
}

(Received 26 May 1988; revised 22 July 1988)

\begin{abstract}
Pre-incubation of cells of Saccharomyces cerevisiae with 2 M-ethanol led to decreased rates of $\mathrm{L}$-alanine uptake, $\mathrm{H}^{+}$efflux and fermentation rate. However, these responses were modified in yeast cells with altered phospholipid composition. Using $\mathrm{L}$-alanine transport and $\mathrm{H}^{+}$effilux as indices of ethanol tolerance, it was observed that cells enriched with phosphatidylserine had greater tolerance to ethanol. This resulted from altered charge of membrane phospholipids rather than changes in membrane fluidity. It is suggested that the anion:zwitterion ratio of phospholipids may be one of the important determinants of ethanol tolerance in $S$. cerevisiae.
\end{abstract}

\section{INTRODUCTION}

It is now established that ethanol accumulation is primarily responsible for inhibiting fermentation. Ethanol at concentrations above $12 \%$ is toxic to yeast (Rose, 1980) and consequently growth ceases at about this concentration. The inhibition by ethanol of growth of Saccharomyces cerevisiae is preceded by the effects of ethanol on cell viability (Thomas et al., 1978; Beavan et al., 1982), accumulation of various nutrients (Thomas \& Rose, 1979; LoureiroDias \& Peinado, 1982; Leẩo \& van Uden, 1982, 1983, 1984a), $\mathrm{H}^{+}$fluxes (Leão \& van Uden, $1984 b$; Cartwright et al., 1986; Juroszek et al., 1986) and on fermentation rate (Casey \& Ingledew, 1986). Similar effects of ethanol are also known in other organisms (Fried \& Novick, 1973; Ingram \& Buttke, 1984; Ingram, 1986).

The plasma membrane is considered to be the prime target of ethanol action in yeast (Ingram \& Buttke, 1984). It seems that both the structure and function of the yeast plasma membrane are affected (Ingram \& Buttke, 1984; Ingram, 1986). Amongst various membrane components, lipids are the chief targets of ethanol toxicity (Thomas et al., 1978; Thomas \& Rose, 1979). Alterations in phospholipid and fatty acyl residue composition in the presence of ethanol is known to be due to an adaptive response to the physiochemical interaction of ethanol with the plasma membrane (Ingram, 1977, 1986). Unsaturated fatty acyl residues and ergosterol are considered to be important determinants of ethanol tolerance in yeast (Thomas et al., 1978; Thomas \& Rose, 1979; Beavan et al., 1982). However, the precise role of phospholipid head groups in resistance to ethanol has not been ascertained. Since ethanol can modify the hydration state of polar head groups (Rigomier et al., 1980) and is equally important in interfacial regulation of lipid-protein interactions (Sandermann, 1978), it was of interest to study the effect of ethanol on the yeast plasma membrane after phospholipid head group modification.

Availability of a yeast lipid auxotroph (chol) and of hydroxylamine chloride, a specific inhibitor of phosphatidylserine decarboxylase (EC 4.1.1.65), have provided an opportunity to enrich yeast plasma membrane with specific phospholipids (Trivedi et al., 1982, 1983). In the present study, using amino acid transport and $\mathrm{H}^{+}$fluxes as indices of membrane function, the role of phospholipids in ethanol tolerance has been investigated.

Abbreviations: DPH, 1,6-diphenyl-1,3,5-hexatriene; PC, phosphatidylcholine; PE, phosphatidylethanolamine; PS, phosphatidylserine. 


\section{METHODS}

Strain and culture conditions. S. cerevisiae $\alpha$ ade5 and its mutant derivative KA101 (chol) were maintained on YEPD slants and enriched with different phospholipid bases as described previously (Trivedi et al., 1982, 1983). Cells were harvested and washed three times with sodium citrate buffer (10 mM, pH 4.5) before use for further studies.

Measurement of rate of amino acid uptake. The transport assay procedure was similar to that described previously (Rao et al., 1986; Mishra \& Prasad, 1987). The rate of L-alanine uptake was determined from plots of the timecourse of uptake up to $195 \mathrm{~s}$ using linear regression analysis. To examine the effect of ethanol on amino acid uptake, 2 mu-ethanol was added to cell suspensions. After preincubation at $30^{\circ} \mathrm{C}$ for $5 \mathrm{~min}$, the reaction was started by the addition of $\mathrm{L}^{-14} \mathrm{Clalanine}\left(37 \mathrm{kBq} \mu \mathrm{mol}^{-1}\right)$. The final concentration of $\mathrm{L}$-alanine was two to four times higher than its $K_{\mathrm{T}}$ value. At the indicated time intervals samples were removed and immediately diluted in $5 \mathrm{ml}$ ice-cold citrate buffer ( $10 \mathrm{mM}, \mathrm{pH} 4-5$ ) containing unlabelled $\mathrm{L}$-alanine at the concentration included in the cell suspension. The diluted suspension was rapidly filtered through $0.45 \mu \mathrm{m}$ pore diameter, Maxflow filter discs. Filters were then washed twice with the same buffer containing unlabelled $L$-alanine and the radioactivity retained was counted in a Beckman LS-1801 Beta liquid scintillation counter using a toluene-based scintillation fluid.

Inhibition constant $K_{\mathrm{i}(\mathrm{ErOH})}$ values for $L$-alanine uptake were derived from reciprocal plots of velocities of L-alanine uptake against increasing concentrations of ethanol $(0.5$ to $2.0 \mathrm{M})$ at two fixed substrate concentrations (Dixon, 1953).

Measurement of rates of proton flux. Glucose-stimulated proton efflux was measured by the addition of glucose $(100 \mathrm{~mm})$ to a suspension (100 mg wet wt $\left.\mathrm{ml}^{-1}\right)$ of cells enriched with different phospholipids. A constant temperature of $30^{\circ} \mathrm{C}$ was maintained by circulating water through a water-jacketted chamber. The cell suspension in the chamber was constantly stirred. Changes in $\mathbf{p H}$ of the suspension were recorded by using a REC 80 Servograph with REA $105 \mathrm{pH} / \mathrm{mV}$ unit (Radiometer). The effect of ethanol on glucose-induced $\mathrm{H}^{+}$effiux was measured by supplementing the cell suspension with ethanol after adjusting its $\mathrm{pH}$ value to $4.0 \mathrm{prior}$ to the addition of glucose (100 mM). Proton flux was then followed over a $5 \mathrm{~min}$ period (Cartwright et al., 1986). The pH range was fixed in order to avoid denaturation of the cellular components of energized organisms (Juroszek et al., 1986).

Fluorescence measurements. A $2 \mathrm{mu}$ solution of 1,6 diphenyl-1,3,5-hexatriene (DPH) was prepared in tetrahydrofuran and $100 \mu \mathrm{l}$ was added to $50 \mathrm{ml}$ of rapidly stirred potassium phosphate buffer (10 mM, pH 6.8). Excess tetrahydrofuran was removed by flushing with nitrogen. Spheroplasts of normal as well as of phospholipidenriched cells were prepared as described previously (Jayakumar et al., 1981). These spheroplasts were washed with phosphate buffer $(20 \mathrm{mM}, \mathrm{pH} 6.0)$ containing $10 \mathrm{mM}-\mathrm{MgSO}_{4}$ and $0.6 \mathrm{M}$-sorbitol and incubated with $2 \mu \mathrm{M}$ DPH for $60 \mathrm{~min}$ at $30^{\circ} \mathrm{C}$. Fluorescence polarization was measured by excitation with monochromatic light at $360 \mathrm{~nm}$ which was vertically polarized, and emission intensity was detected at $426 \mathrm{~nm}$ through an analyser oriented either parallel or perpendicular to the direction of polarized excitation light. The degree of fluorescence polarization $(p)$ and anisotropy $(r)$ were calculated according to Haggerty $e t$ al. (1976).

Measurement of fermentation rates. The ability of $S$. cerevisiae to ferment glucose was determined with a Gilson single-valve differential respirometer. Cells $\left(100 \mathrm{mg}\right.$ wet wt $\left.\mathrm{ml}^{-1}\right)$ were suspended in citrate buffer $(50 \mathrm{mM}$; pH 4.5). Glucose ( $300 \mathrm{mu}$ ) placed in the side arm of the Warburg flasks was mixed with the cell suspension after equilibration for $10 \mathrm{~min}$ at $30^{\circ} \mathrm{C}$. Prior to the addition of glucose, flasks were shaken ( 95 oscillations $\mathrm{min}^{-1}$ ) and the system was continuously flushed with nitrogen gas passed through a trap containing pyrogallol solution. The supply of nitrogen gas was cut off before addition of glucose solution to the buffered cell suspension. Evolution of $\mathrm{CO}_{2}$ was then followed over a period of $5 \mathrm{~min}$ (Cartwright et al., 1986).

Chemicals. Ethanolamine, choline chloride, hydroxylamine, DPH, tetrahydrofuran, L-alanine and standard phospholipids were purchased from Sigma. $L-\left[{ }^{14} \mathrm{C}\right]$ Alanine was purchased from BARC, India. All other chemicals were of analytical grade.

\section{RESULTS AND DISCUSSION}

\section{Phospholipid head group modification in S. cerevisiae}

The $S$. cerevisiae auxotrophic mutant chol uses the CDP choline pathway (Atkinson et al., 1980) for the synthesis of phosphatidylcholine (PC) and phosphatidylethanolamine (PE), and requires phospholipid bases (choline or ethanolamine) for its growth. We have earlier shown that supplementation of this mutant with choline $(1 \mathrm{mM})$ or ethanolamine $(1 \mathrm{mM})$ resulted in the enrichment of PC (18\%) or PE (32\%), respectively (Trivedi et al., 1982). The addition of $20 \mathrm{mM}-$ hydroxylamine to exponentially growing cells led to a 3.5-fold increase in phosphatidylserine (PS) content because hydroxylamine blocks PS decarboxylase and prevents further conversion of PS to other phospholipids (Trivedi et al., 1983). The phospholipid composition of the mutant and of other strains has been published previously (Trivedi et al., 1982, 1983). 
Table 1. Effect of ethanol on L-alanine uptake in S. cerevisiae

Cells were grown in the presence of choline, ethanolamine or hydroxylamine as described in Methods. Velocities were calculated from the linear segment of the time-course of $L$-alanine uptake up to $195 \mathrm{~s}$ using linear regression analysis (Mishra \& Prasad, 1987). To examine the effect of ethanol on L-alanine uptake, cells were incubated in the presence of ethanol $(2 \mathrm{M})$ for $10 \mathrm{~min}$ before the start of transport measurements. Each value is the mean of three experiments.

\begin{tabular}{|c|c|c|c|c|}
\hline \multirow[b]{2}{*}{ Strain } & \multirow[b]{2}{*}{$\begin{array}{l}\text { Supplement } \\
\text { to medium }\end{array}$} & \multicolumn{3}{|c|}{$\begin{array}{l}\text { Velocity of L-alanine uptake } \\
\left.\text { [pmol (mg dry wt) })^{-1} \mathrm{~s}^{-1}\right]\end{array}$} \\
\hline & & $\begin{array}{l}\text { Without } \\
\text { ethanol }\end{array}$ & $\begin{array}{c}\text { With } \\
\text { 2 M-ethanol }\end{array}$ & $\begin{array}{l}\text { Percentage } \\
\text { inhibition by } \\
2 \text { M-ethanol }\end{array}$ \\
\hline $\begin{array}{l}\alpha \text { ades } \\
\text { chol } \\
\text { chol } \\
\alpha \text { ade } 5\end{array}$ & $\begin{array}{l}\text { None } \\
\text { Choline (1 mu) } \\
\text { Ethanolamine (1 mM) } \\
\text { Hydroxylamine ( } 20 \mathrm{mM})\end{array}$ & $\begin{array}{l}6 \cdot 5 \\
5 \cdot 7 \\
2 \cdot 3 \\
7 \cdot 0\end{array}$ & $\begin{array}{l}2 \cdot 5 \\
1 \cdot 3 \\
0.8 \\
5 \cdot 0\end{array}$ & $\begin{array}{l}61 \\
77 \\
65 \\
28\end{array}$ \\
\hline
\end{tabular}

Table 2. Inhibition constants $\left(K_{i(\mathrm{ErOH})}\right)$ for L-alanine uptake in $S$. cerevisiae

$\boldsymbol{K}_{\mathrm{i}(\mathrm{E} \mathrm{KOH})}$ values were derived from Dixon plots. Velocity of $\mathrm{L}$-alanine uptake was calculated as deacribed in Methods using linear regression analysis. Values are means of three experiments \pm SD values.

\begin{tabular}{|c|c|c|c|c|}
\hline Strain & $\begin{array}{l}\text { Supplement } \\
\text { to medium }\end{array}$ & $\begin{array}{l}\text { Cells enriched } \\
\text { with: }\end{array}$ & $\begin{array}{c}\text { Type of } \\
\text { inhibition }\end{array}$ & $\begin{array}{c}10^{-2} \times K_{\mathrm{i}(\mathrm{EHOH})} \\
(\mathrm{M})\end{array}$ \\
\hline $\begin{array}{l}\alpha \text { ade5 } \\
\text { chol } \\
\text { chol } \\
\text { a ade5 }\end{array}$ & $\begin{array}{l}\text { None } \\
\text { Choline (1 mu) } \\
\text { Ethanolamine (1 mM) } \\
\text { Hydroxylamine ( } 20 \mathrm{mM})\end{array}$ & $\begin{array}{l}\text { No enrichment } \\
\text { PC } \\
\text { PE } \\
\text { PS }\end{array}$ & $\begin{array}{l}\text { Non-competitive } \\
\text { Non-competitive } \\
\text { Non-competitive } \\
\text { Non-competitive }\end{array}$ & $\begin{array}{l}50.0 \pm 2.0 \\
12.5 \pm 0.6 \\
25.0 \pm 1.1 \\
75.0 \pm 2.5\end{array}$ \\
\hline
\end{tabular}

\section{Effect of ethanol on amino acid uptake in S. cerevisiae}

Cells enriched with specific phospholipids were tested for their ability to tolerate ethanol. Amino acid uptake was used as an index of membrane function (Thomas \& Rose, 1979; Prasad \& Rose, 1986). When wild-type ( $\alpha$ ade5) and cells enriched with PC, PE or PS were incubated with $2 \mathrm{M}$-ethanol for $10 \mathrm{~min}$, the rate of $\mathrm{L}$-alanine uptake was reduced in the following order: PC $(77 \%)>$ PE $(65 \%)>\alpha$ ade $5(61 \%)>$ PS $(28 \%)$ (Table 1$)$. The extent of inhibition of L-alanine uptake in the presence of ethanol was minimal in PS-enriched cells. Thus, it is possible that PS enrichment of yeast plasma membrane confers greater tolerance to ethanol in comparison to enrichment with other phospholipids.

To gain further insight into the inhibition by ethanol of L-alanine uptake, the inhibitory constant $K_{\mathrm{i}(\mathrm{EtOH})}$ was determined at two different concentrations of L-alanine with increasing concentrations of ethanol $(0.5$ to $2.0 \mathrm{M})$. A non-competitive inhibition by ethanol of L-alanine uptake was evident from Dixon plots (not shown), which confirmed earlier observations (Leão \& van Uden, 1984a, $b$; Cartwright et al., 1987). $K_{\mathrm{i}(\mathrm{ErOH})}$ values (Table 2) further indicated that the inhibitory effect of ethanol was in the order PC $>$ PE $>\alpha$ ade5 $>$ PS-enriched cells. Maximum $K_{\mathrm{i}(\mathrm{EtOH})}$ value in PS-enriched cells indicated minimal inhibitory effect of ethanol on L-alanine uptake (Table 2).

\section{Effect of ethanol on $\mathrm{H}^{+}$efflux in $\mathrm{S}$. cerevisiae}

Earlier studies by Rose and co-workers demonstrated that the addition of glucose $(100 \mathrm{~mm})$ to yeast cell suspensions results in a rapid acidification of the external medium (Cartwright et al., 1986), due to net proton efflux caused by $\mathbf{M g}^{2+}$-dependent proton translocating ATPase (Willsky, 1979; Malpartida \& Serrano, 1981). Addition of increasing concentrations of ethanol results in an increase in extracellular $\mathrm{pH}$ by decreasing the proton efflux (Cartwright $e t$ al., 1986). 

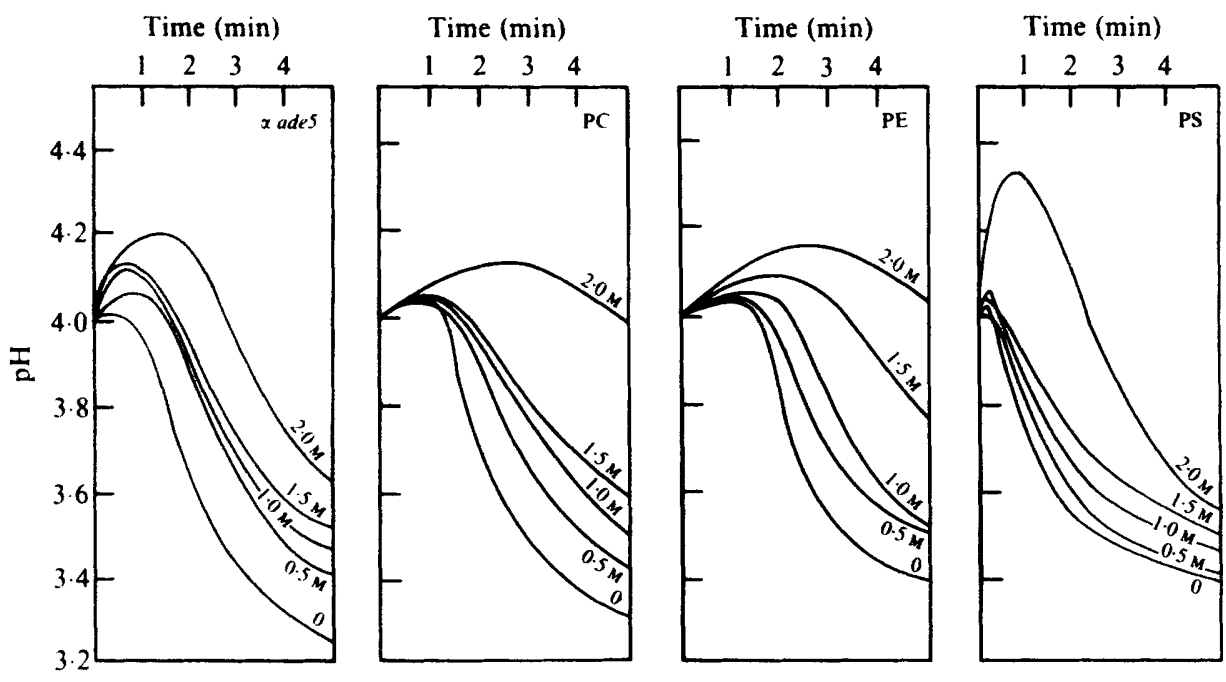

Fig. 1. Effect of ethanol (at the concentration indicated) on the ability of energized $S$. cerevisiae cells to acidify the external medium. The lines are direct tracings of a typical experiment. The initial $\mathrm{pH}$ of the cell suspension was adjusted to $\mathrm{pH}$ 4-0. Other details were similar to those described in Methods. The four panels of tracings represent experiments done with non-enriched $\alpha$ ade 5 or $\alpha$ ade 5 cells enriched with PC, PE or PS.

Table 3. Effect of ethanol on fermentative activity of $S$. cerevisiae

Cells were suspended in citrate buffer (pH 4.5, $50 \mathrm{~mm}$ ) and fermentation rates were measured as described in Methods. The percentage inhibition values were calculated from the mean of three sets of observations; the extent of variation was within $5 \%$.

\section{Strain}

a ades

chol

chol

$\alpha$ ades
Cells enriched with:

No enrichment

Phosphatidylcholine

Phosphatidylethanolamine

Phosphatidylserine

\section{Percentage inhibition of fermentative} activity by $2 \mathrm{M}$-ethanol

Our data indicated that ethanol-induced reversal of $\mathrm{H}^{+}$efflux is affected by modification of the phospholipid head group. Rapid acidification of a normal cell suspension was prevented by ethanol in a concentration-dependent manner (Fig. 1). The inhibition of $\mathrm{H}^{+}$efflux at various concentrations of ethanol was evident from the increase in extracellular $\mathrm{pH}$. Similar to L-alanine uptake, $\mathrm{H}^{+}$efflux was least affected in PS-enriched cells.

From the results of $\mathrm{H}^{+}$flux and L-alanine uptake experiments, it became apparent that phospholipid enrichment offers some protection against ethanol toxicity; this protection was greatest in PS-enriched cells. The way in which PS enrichment can affect ethanol toxicity is not clear. There are reports suggesting that an increased ratio of anionic:zwitterionic phospholipids can affect ethanol tolerance (Clark \& Beard, 1979; Bohin \& Lubochinsky, 1982). It has also been suggested that the phospholipid head group could modify the effect of ethanol on plasma membrane ATPase activity (Stadtlander et al., 1982). Based on $\mathrm{H}^{+}$-flux measurements, our data do suggest that in PS-enriched cells, $\mathrm{H}^{+}$-translocating activity of ATPase becomes less sensitive to ethanol as compared to wild-type, PC- or PE-enriched cells (Fig. 1).

\section{Effect of ethanol on fermentative activity of $S$. cerevisiae}

The inhibition of the fermentative ability of an organism in the presence of ethanol is the best indicator of the potential of a given strain to produce ethanol (Casey \& Ingledew, 1986). This is 


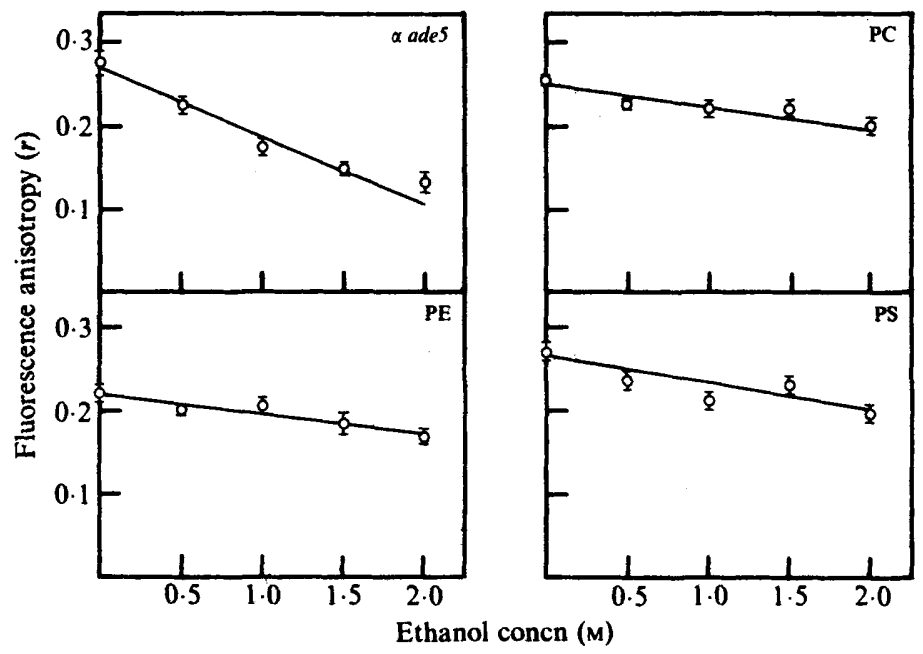

Fig. 2. Effect of ethanol on the anisotropic value $(r)$. Spheroplasts were prepared either from nonenriched $\alpha$ ade5 or $\alpha$ ade5 cells enriched with PC, PE or PS. Anisotropic measurements were done as described in Methods. The four panels represent the anisotropic values of the different cell types. Each point is the mean of three separate determinations; the vertical bars represent \pm SEM.

because the effect of ethanol on fermentation rate is not influenced by the nutritional conditions or the growth status of the cells and its value correlates well with the upper limits of ethanol production (Hayashida \& Ohta, 1981).

Among cells enriched with various phospholipids the rate of fermentation was greatest in PSenriched cells and was comparable to that of wild-type cells (data not shown). The percentage inhibition of fermentation by 2 M-ethanol was least in PS-enriched cells. The fermentative abilities of cells of $S$. cerevisiae with altered phospholipid compositions suggest that those enriched with PS acquire the greatest resistance to ethanol (Table 3).

\section{Effect of ethanol on membrane fuidity in $S$. cerevisiae}

Ethanol interacts with and perturbs the organization of lipid bilayers (Paterson et al., 1972; Jain \& Wu, 1977); in particular it lowers the transition temperature and increases membrane fluidity (Jain \& Wu, 1977). Since addition of ethanol results in a reduction in dielectric strength and thereby leads to altered charge interaction at the phospholipid surface (Fried \& Novick, 1973), it was of interest to monitor the effect of ethanol on the fluidity of yeast plasma membrane enriched with different phospholipids. We therefore used DPH, a fluorescent probe, to monitor changes in membrane fluidity (Van-Blitterswijk et al., 1987). As revealed by the anisotropic data, except in PE-enriched cells the alteration in phospholipid head group did not significantly alter the membrane fluidity as compared to wild-type cells. However, increasing concentrations of ethanol led to decreased anisotropy or increased fluidity (Fig. 2). The decrease in anisotropy suggests that the fluidizing effect of ethanol was greater in $\alpha$ ade5 cells as compared to cells enriched in different phospholipids.

Since the fluidity (anisotropy) of the membrane was not affected by a change in phospholipid head group, the ethanol tolerance of cells enriched in PS must reflect lipid properties other than fluidity (Cartwright et al., 1986). In this regard Jones \& Greenfield (1987), using passive permeability of acetic acid as a criterion of membrane fluidity, showed that optimum membrane stability rather than increased membrane fluidity is of greater relevance to ethanol tolerance in yeast.

Apart from the long-term effect of ethanol on the yeast cell membrane, where adaptation results in the alteration of fatty acyl composition (Ingram, 1976), the short-term effects of ethanol on membrane functions are equally important. Our results, based on amino acid uptake, $\mathrm{H}^{+}$efflux and fermentative activity suggest that head group composition rather than fluidity 
renders yeast membranes more resistant to ethanol. The role of membrane fluidity, however, cannot be overlooked (Thomas et al., 1978; Thomas \& Rose, 1979). Recent results from our laboratory further confirm earlier findings of Rose and co-workers (Thomas et al., 1978; Thomas \& Rose, 1979) that the degree of unsaturation is a decisive factor in ethanol tolerance when other membrane components remain unaltered (unpublished observations).

P. Mishra gratefully acknowledges an SRF award from CSIR, New Delhi, India. This work was supported in part by a grant from the Department of Science \& Technology [no. 22 (7P/22) 84 STP II], New Delhi, India and from the Indian Council of Medical Research [5/11(1)87-BMS-II(8700080)]. Special assistance from the University Grant Commission under COSIST is also acknowledged.

\section{REFERENCES}

Atrinson, K., Fogel, S. \& Henry, S. A. (1980). Yeast mutants defective in phosphatidylserine synthesis. Journal of Biological Chemistry 255, 6653-6661.

Beavan, M. J., Charpentier, C. \& Rose, A. H. (1982). Production and tolerance of ethanol in relation to phospholipid fatty-acyl composition in Saccharomyces cerevisiae. Journal of General Microbiology 128, $1447-1455$.

BohIN, J. P. \& Lubochinsixy, B. (1982). Alcoholresistant sporulation mutants of Bacillus subtilis. Journal of Bacteriology 150, 944-955.

Cartwright, C. P., Juroszek, J., Beavan, M. J., Ruby, F. M., De Morais, S. F. M. \& Rose, A. H. (1986). Ethanol dissipates the proton-motive force across the plasma membrane of Saccharomyces cerevisiae. Journal of General Microbiology 132, 369377.

Cartwright, C. P., Veazey, F. J. \& Rose, A. H. (1987). Effect of ethanol on activity of the plasma membrane ATPase in, and accumulation of glycine by Saccharomyces cerevisiae. Journal of General Microbiology 133, 857-865.

CASEY G. P. \& INGLEDEW, W. M. (1986). Ethanol tolerance in yeasts. CRC Critical Reviews in Microbiology 13, 219-280.

Clark, D. P. \& Beard, J. P. (1979). Altered phospholipid composition in mutants of Escherichia coli sensitive or resistant to organic solvents. Journal of General Microbiology 113, 267-274.

Drxon, M. (1953). The determination of enzyme inhibition constants. Biochemical Journal 55, 170171.

Fried, V. A. \& Novick, A. (1973). Organic solvents as probes for the structure and function of bacterial membrane: ethanol-resistant mutant of Escherichia coli K-12. Journal of Bacteriology 114, 239-248.

Haggerty, D. F., Kalara, V. K., Popjak, G., ReYNold, E. E. \& ChIAppelle, F. (1978). Fluorescence polarization measurements on normal and mutant human skin fibroblasts. Archives of Biochemistry and Biophysics 189, 51-62.

HAYASHIDA, S. \& OrTA, K. (1981). Formation of high concentrations of alcohols by various yeasts. Journal of the Institute of Brewing 87, 42-46.

INGRAM, L. O. (1976). Adaptation of membrane lipids to alcohols. Journal of Bacteriology 125, 670-678.

INGRaM, L. O. (1977). Preferential inhibition of phosphatidylethanolamine synthesis in $E$. coli by alcohols. Canadian Journal of Microbiology 23, 779789.

INGRAM, L. O. (1986). Microbial tolerance to alcohol: role of the cell membrane. Trends in Biotechnology 4 , 40-44.

INGRAM, L. O. \& BuTtKe, T. M. (1984). Effects of alcohols on microorganisms. Advances in Microbial Physiology 25, 253-300.

JAN, M. K. \& WU, N. M. (1977). Effect of small molecules on the dipalmitoyllecithin liposomal bilayers: phase transition in lipid bilayer. Journal of Membrane Biology 34, 157-201.

Jayarumar, A., Singh, M., Verma, R. S., Baquer, N. Z. \& Prasad, R. (1981). Characteristics of proline transport in the spheroplasts isolated from Candida albicans. Indian Journal of Biochemistry and Biophysics 18, 206-210.

JONES, R. P. \& GREENFIELD, P. F. (1987). Ethanol and fluidity of yeast plasma membrane. Yeast 3, 223232.

Juroszex, K. J., Feuillat, M. \& Charpentier, C. (1986). Effect of ethanol on the glucose induced movements of protons across the plasma membrane of Saccharomyces cerevisiae NCYC 431. Canadian Journal of Microbiology 33, 93-97.

LEÃo, C. \& VAN UDEN, N. (1982). Effect of ethanol on glucose transport systems of Saccharomyces cerevisiae. Biotechnology and Bioengineering 24, 2601-2604.

LEÃo, C. \& VAN UDEN, N. (1983). Effect of ethanol on the ammonium transport systems of Saccharomyces cerevisiae. Biotechnology and Bioengineering 25, 20852089.

LEÃO, C. \& VAN UDEN, N. (1984a). Effect of ethanol and other alkanols on the general amino acid permease of Saccharomyces cerevisiae. Biotechnology and Bioengineering 26, 403-405.

LEÃO, C. \& VAN UDEN, N. (1984b). Effect of ethanol and other alkanols on passive proton influx in the yeast Saccharomyces cerevisiae. Biochimica et biophysica acta 774, 43-48.

Loureiro-Dias, M. C. \& Peinado, J. M. (1982). Effect of ethanol and other alkanols on the maltose transport systems of Saccharomyces cerevisiae. Biotechnology Letters 11, 721-724.

Malpartida, F. \& Serrano, R. (1981). Proton translocation catalyzed by the purified yeast plasma membrane ATPase reconstituted in liposomes. FEBS Letters 131, 351-354.

Mishra, P. \& PrasAd, R. (1987). Alterations in fatty acyl composition can selectively affect amino acid transport in Saccharomyces cerevisiae. Biochemistry International 15, 499-508.

Paterson, S. J., Butler, K. W., Huang, P., Labelle, J., SMITH, C. P. \& SCHNEIDER, H. (1972). The effect 
of alcohols on lipid bilayers: a spin label study. Biochimica et biophysica acta 266, 597-602.

Prasad, R. \& Rose, A. H. (1986). Involvement of lipids in solute transport in yeasts. Yeast 2, 205220.

Rao, L. R. S., Prasad, D. S. \& Prasad, R. (1986). Transport of basic amino acids in Candida albicans. Biochimica et biophysica acta 856, 237-243.

Rigomier, D., BOHIN, J. P. \& LUBOCHINSKY, B. (1980). Effects of ethanol and methanol on lipid metabolism in Bacillus subtilis. Journal of General Microbiology 121, 139-149.

Rose, A. H. (1980). Recent research on industrially important strains of Saccharomyces cerevisiae. In Biology and Activity of Yeast, pp. 103-121. Edited by F. A. Skinner, S. M. Passmore \& R. R. Davenport. London: Academic Press.

SANDERMANN, H. (1978). Regulation of membrane enzymes by lipids. Biochimica et biophysica acta 515, 209-237.

Stadtlander, K., Rade, S. \& Ahlers, J. (1982). Influence on the plasma membrane from yeast and on kinetic properties of two membrane functions. Journal of Cellular Biochemistry 20, 369-380.

Thomas, S. D., Hossack, J. A. \& Rose, A. H. (1978). Plasma membrane lipid composition and ethanol tolerance in Saccharomyces cerevisiae. Archives of Microbiology 117, 239-245.

Thomas, S. D. \& Rose, A. H. (1979). Inhibitory effect of ethanol on growth and solute accumulation by Saccharomyces cerevisiae as affected by plasma membrane composition. Archives of Microbiology 122, 49-55.

Trivedi, A., Khare, S., Singhal, G. S. \& Prasad, R. (1982). Effect of phosphatidylcholine and phosphatidylethanolamine enrichment on the structure and function of yeast membrane. Biochimica et biophysica acta 692, 202-209.

Trivedi, A., Singhul, G. S. \& Prasad, R. (1983). Effect of phosphatidylserine enrichment on amino acid transport in yeast. Biochimica et biophysica acta 729, 85-89.

Van-Blitterswitx, W. J., Van Dermebr, B. W. \& HILKMANN, H. (1987). Quantitative contributions of cholesterol and individual classes of phospholipids and their degree of fatty acyl unsaturation to membrane fluidity measured by fluorescence polarization. Biochemistry 26, 1746-1757.

WILLSKY, G. R. (1979). Characteristics of the plasma membrane $\mathbf{M g}^{++}$-ATPase from the yeast Saccharomyces cerevisiae. Journal of Biological Chemistry 254, 3326-3332. 